\title{
Unusual cause of sinusitis and cough
}

\author{
Grecia Aldana, ${ }^{1}$ Carlos A Jimenez, ${ }^{1}$ Cesar Moran ${ }^{2}$
}

'Pulmonary Medicine, MD Anderson Cancer Center, Houston, Texas, USA ${ }^{2}$ Pathology Medicine, University of Texas MD Anderson Cancer Center, Houston, Texas, USA

\section{Correspondence to}

Dr Carlos A Jimenez,

cajimenez@mdanderson.org

Accepted 14 June 2018

D Check for updates

(c) BMJ Publishing Group Limited. No commercial re-use. See rights and permissions. Published by BMJ.

\section{To cite: Aldana $\mathrm{G}$}

Jimenez CA, Moran C. BMJ

Case Rep Published Online

First: [please include Day

Month Year]. doi:10.1136/

bcr-2018-225829

\section{DESCRIPTION}

A 60-year-old woman with chronic lymphocytic leukaemia (CLL) previously treated with ofatumumab was referred for evaluation of worsening productive cough, sinus pain and nasal congestion. She had received multiple courses of antibiotics, antifungals and steroids with partial symptomatic improvement. CT of the chest demonstrated bilateral bronchial wall thickening and bronchial dilatation associated with patchy opacities (figure 1A). An open lung biopsy revealed a dense monotonous lymphocytic infiltrate in a bronchiolocentric distribution sparing the lung parenchyma with associated vague non-caseating granulomatous inflammation and focal areas of organising pneumonia. These findings suggested pulmonary involvement by CLL (figure 1B, C). Nasal and paranasal sinus biopsies were also consistent with

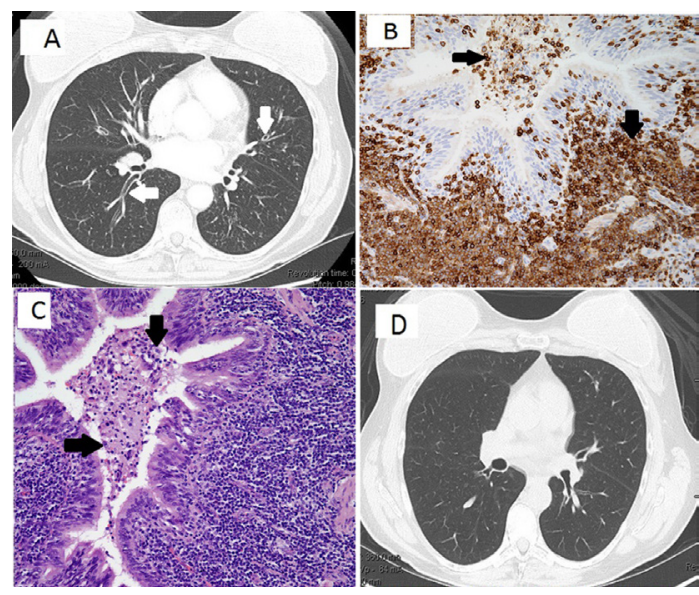

Figure 1 (A) CT of the chest demonstrating bilateral bronchial wall thickening and bronchial dilatation associated with patchy opacities. (B) Lung biopsy with immunohistochemical stain for $\mathrm{CD} 5$ shows positive staining in the lymphocytic component (black arrows). (C) Lung biopsy showing dense monotonous lymphocytic infiltrate around airway (black arrows). (D) CT of the chest demonstrating resolution of previous patchy opacities.
CLL. She was started on salvage therapy with ibrutinib. Sinus, nasal and pulmonary symptoms resolved completely after 4 months without the need for additional antibacterial or antifungal medication. Repeat imaging showed resolution of opacities (figure 1D). The majority of pulmonary infiltrates in patients with CLL have an infectious aetiology; however, malignant involvement of the lung parenchyma by leukaemia might have similar radiological findings. ${ }^{1}$ Malignant leukaemic involvement of the lung must be considered in any patient with leukaemia presenting with respiratory symptoms. ${ }^{2}$ Prompt exclusion of infectious aetiologies expedites appropriate treatment and subsequently improves clinical outcomes.

\section{Learning points}

- Malignant leukaemic involvement of the lung must be considered in any patient with leukaemia presenting with respiratory symptoms.

- Prompt exclusion of infectious aetiologies expedites appropiate treatment and subsequently improves clinical outcomes.

Contributors GLA, CAJ, CAM: conception and design, acquisition of radiological and pathological data, drafting the article, critical revision of intellectual content and final approval of the version to be published.

Funding This research received no specific grant from any funding agency in the public, commercial or not-for-profit sectors.

Competing interests None declared.

Patient consent Obtained.

Provenance and peer review Not commissioned; externally peer reviewed.

\section{REFERENCES}

1 Hill BT, Weil AC, Kalaycio M, et al. Pulmonary involvement by chronic lymphocytic leukemia/small lymphocytic lymphoma is a specific pathologic finding independent of inflammatory infiltration. Leuk Lymphoma 2012:53:589-95.

2 Wu YK, Huang YC, Huang SF, et al. Acute respiratory distress syndrome caused by leukemic infiltration of the lung. J Formos Med Assoc 2008;107:419-23.

Copyright 2018 BMJ Publishing Group. All rights reserved. For permission to reuse any of this content visit

http://group.bmj.com/group/rights-licensing/permissions.

BMJ Case Report Fellows may re-use this article for personal use and teaching without any further permission.

Become a Fellow of BMJ Case Reports today and you can:

- Submit as many cases as you like

- Enjoy fast sympathetic peer review and rapid publication of accepted articles

- Access all the published articles

- Re-use any of the published material for personal use and teaching without further permission

For information on Institutional Fellowships contact consortiasales@bmjgroup.com

Visit casereports.bmj.com for more articles like this and to become a Fellow 